\title{
THE EASTERN BLUEBIRD AT DAUPHIN, MANITOBA
}

WILLIAM J. WALLEY, 19 Edgar Ave., Dauphin, Manitoba, R7N OR4 and WILLIAM L. CLARK, 104 Wellington Crescent, Dauphin, Manitoba. R7N 017

Dauphin, Manitoba $\left(51^{\circ} 05^{\prime} \mathrm{N}, 100^{\circ}\right.$ $05^{\prime} \mathrm{W}$ ) is located on the northern fringe of the geographical range of the Eastern Bluebird and near the northeastern edge of the range of the Mountain Bluebird.' Despite regular birding excursions in the Dauphin area between 1971 and 1981, alarmingly few bluebirds were identified by the authors and associates. With the exception of two rural residences where bluebirds nested in nest boxes in some years during this period only one confirmed nesting was known to us (Table 1). With our concern for an apparently low population of bluebirds at Dauphin, 30 nest boxes were built by us in the late winter of 1981. H.M. Cobbe, Building Construction Instructor at the Dauphin Regional Comprehensive Secondary School, when approached, had his students build 35 nest boxes from scrap lumber that spring and an additional 35 the following winter.

In the spring of 1981, 65 nest boxes were erected southeast, southwest and northwest of Dauphin, often in areas where bluebirds had been sighted over the years and in places believed to constitute good bluebird habitat, i.e. closely grazed pastures with small groves of aspen (Populus tremuloides) or scattered trees - mostly aspen, or both. Unfortunately, because of the preponderance of cultivated fields in the area, not all boxes were put up in what we considered to be good habitat. Frequently, suitable pastures occurred close to farm buildings, but such sites were nearly always avoided in the anticipation that bluebirds would be brought into competition with House Sparrows. Shrubby areas were shunned to discourage House Wrens. About 100 nest boxes were maintained in
1982 and again in 1983 as the trail was extended to include the area northeast of Dauphin. However, without a single bluebird nesting or sighting in that area in two years, these boxes were removed in the fall of 1983 and only 84 nest boxes were operated in 1984.

The most striking feature of the Dauphin nest box study over the first four seasons of its operation has been the absence of breeding Mountain Bluebirds (Table 2). This species nested at A. Pitch's $5 \mathrm{~km}$ northwest of Dauphin in 1975, 1976 and 1977 (Table 1), but we know of no other nestings for this area although the occasional summer occurrence of the Mountain Bluebird has been observed, but not recorded, by municipal grader operator Terry Jenkins (pers. comm.). Although bluebird sightings by the authors were few between 1971 and 1981, the Mountain was recorded much more frequently than the Eastern (Table 1). However, we have not positively identified a Mountain Bluebird in the Dauphin area since 2 males were seen together 1 April 1981 - the first spring that the nest boxes were set out! The only sight records of which we know since that date was one seen by $A$. and R. Pitch northwest of Dauphin 7 April 1983 and a pair that were seen southeast of Dauphin by Robert Carmichael at the Carmichael farm 25 March 1984. On the other hand, 23 successful nestings of Eastern Bluebirds were monitored between 1981 and 1984 (Table 2). With one exception, these are the only nesting records of this species in the area known to us since a family which included 6 young visited the Pitch farm 20 July 1975. 


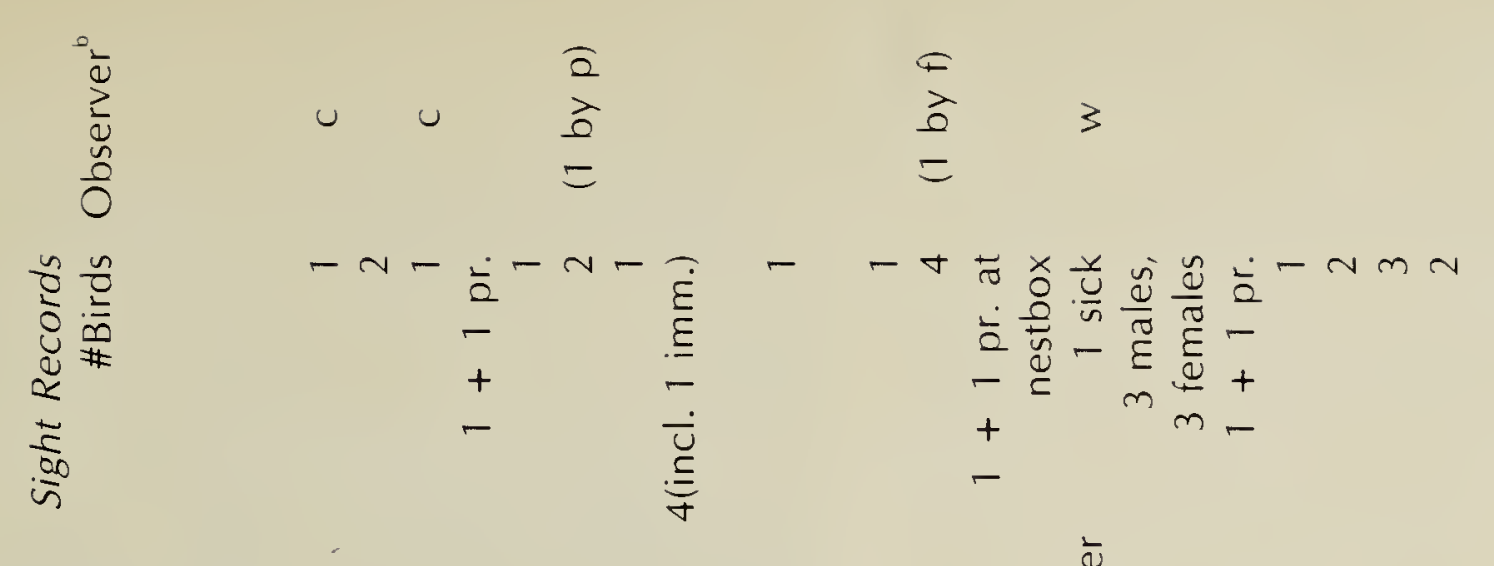

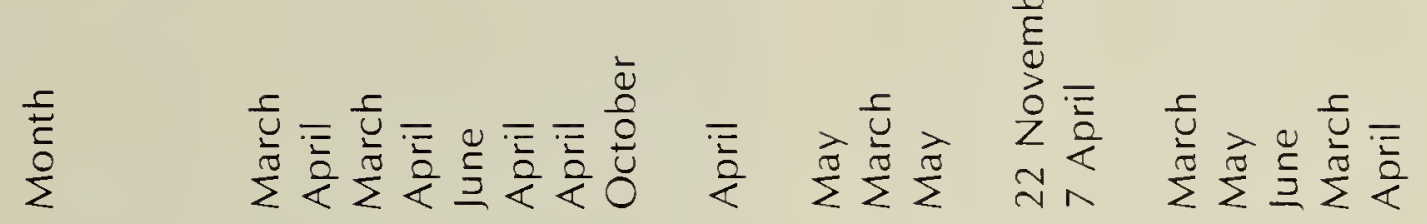

s

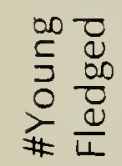

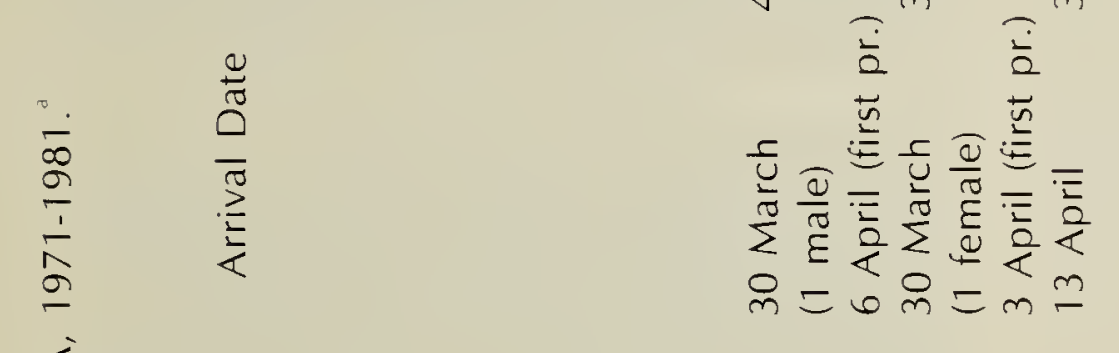

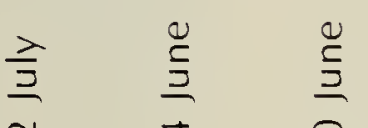

ขี

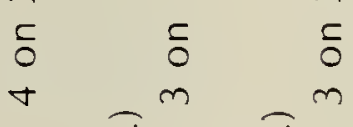

高

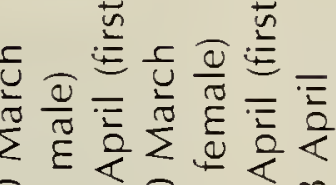

$m=\emptyset m=m m$

$\frac{\mathbb{4}}{\alpha}$

2

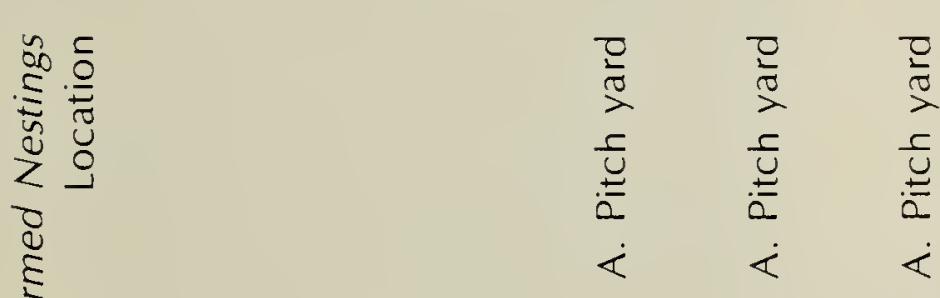

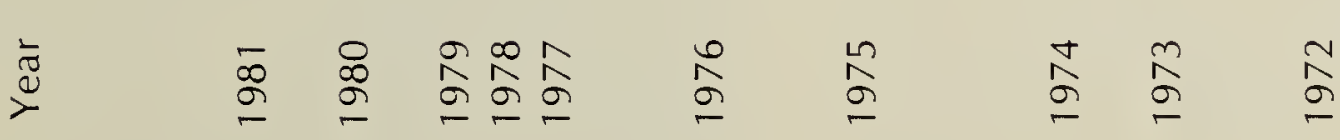

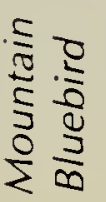

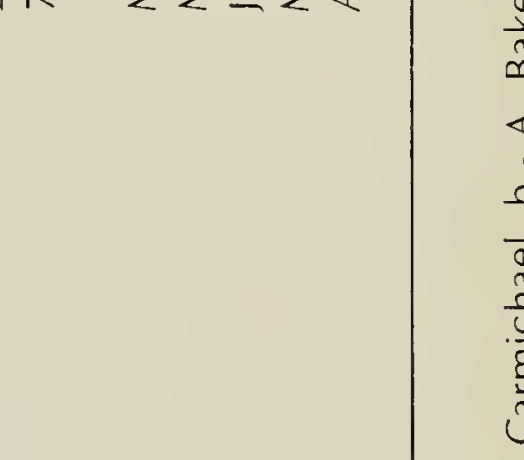$$
\dot{0}
$$

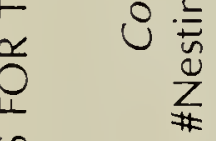

然n n n n

$\underset{\mathrm{U}}{\alpha}$ 


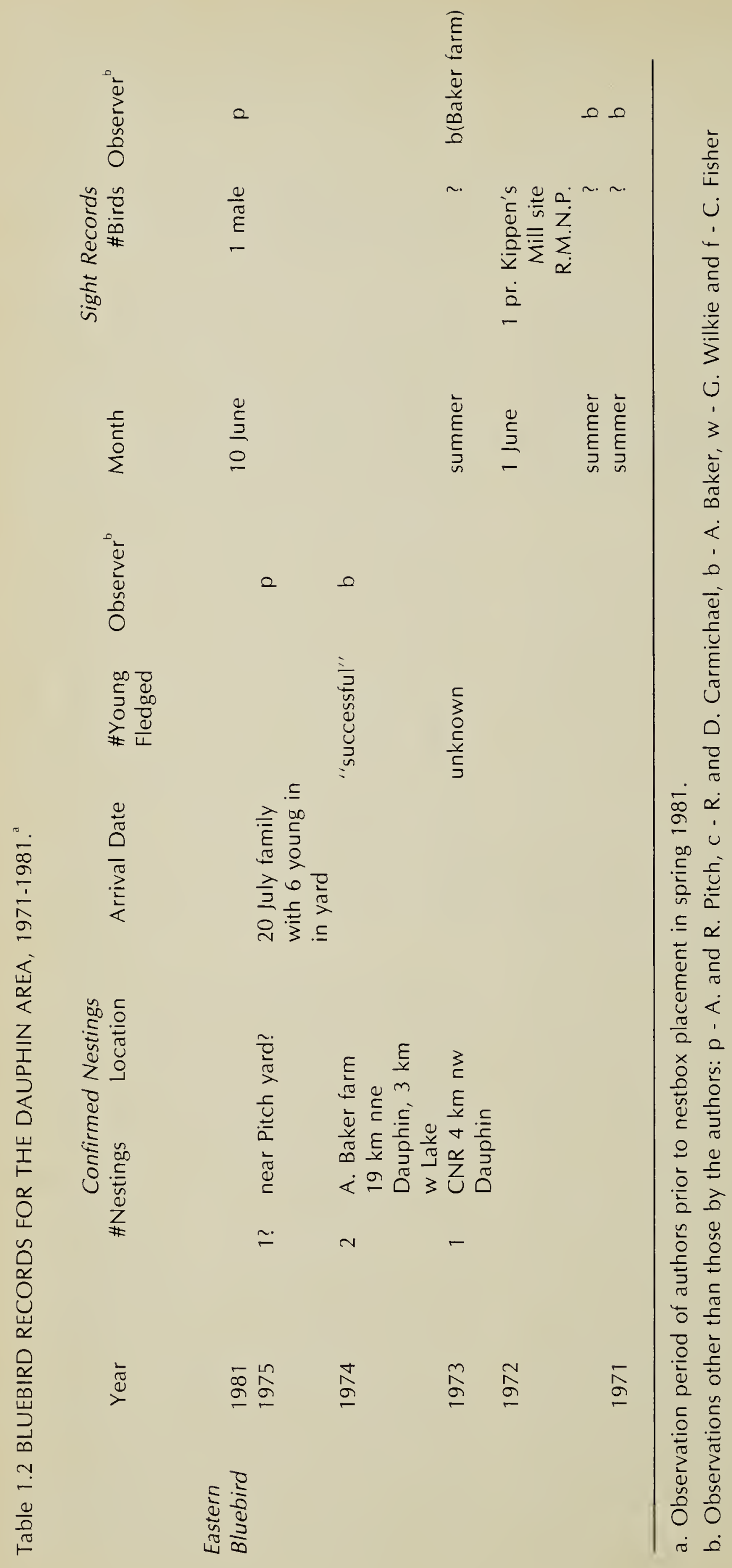


While the mortality of young between fledging and breeding is not known, it

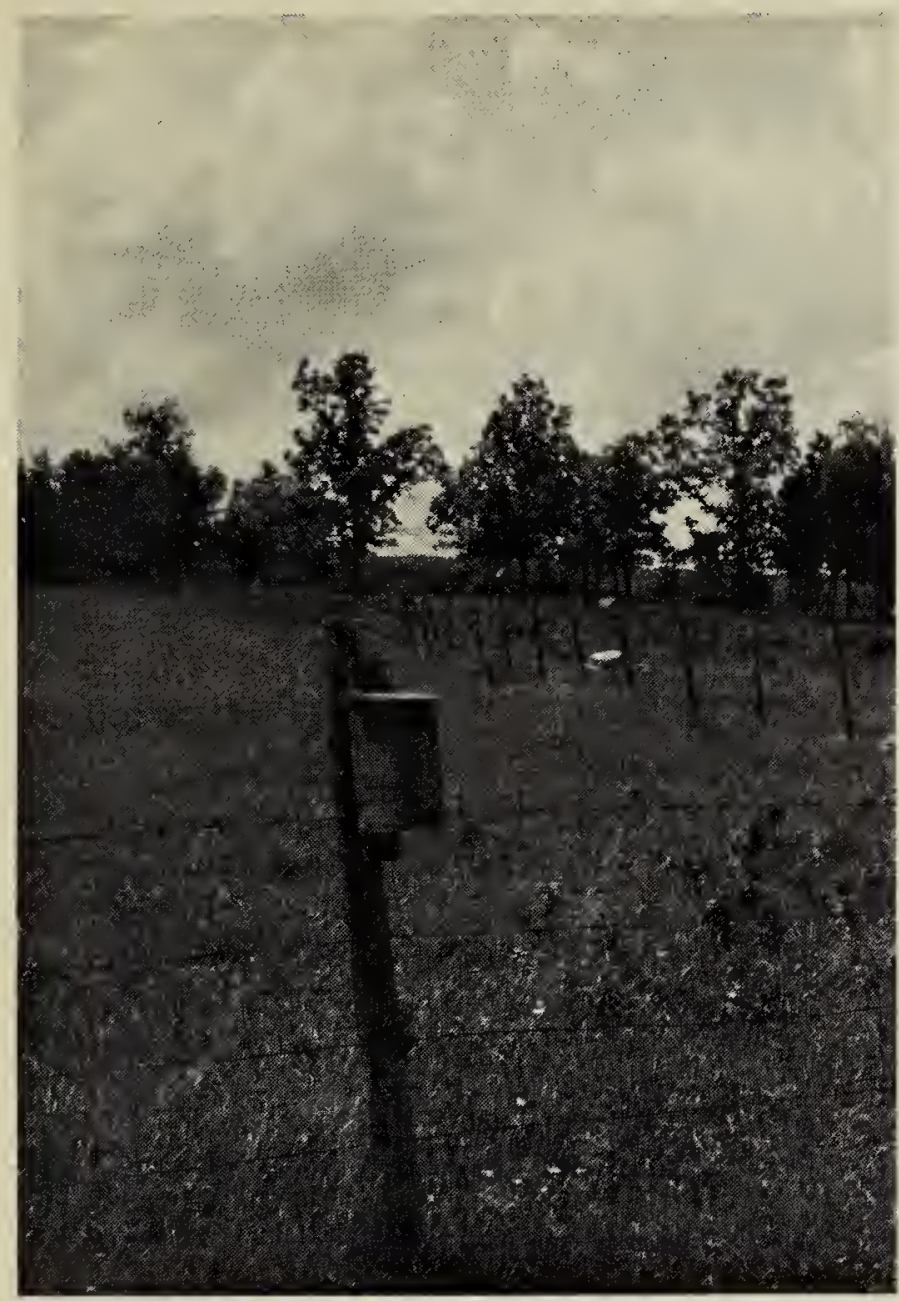

\section{Carmichael-Durston area}

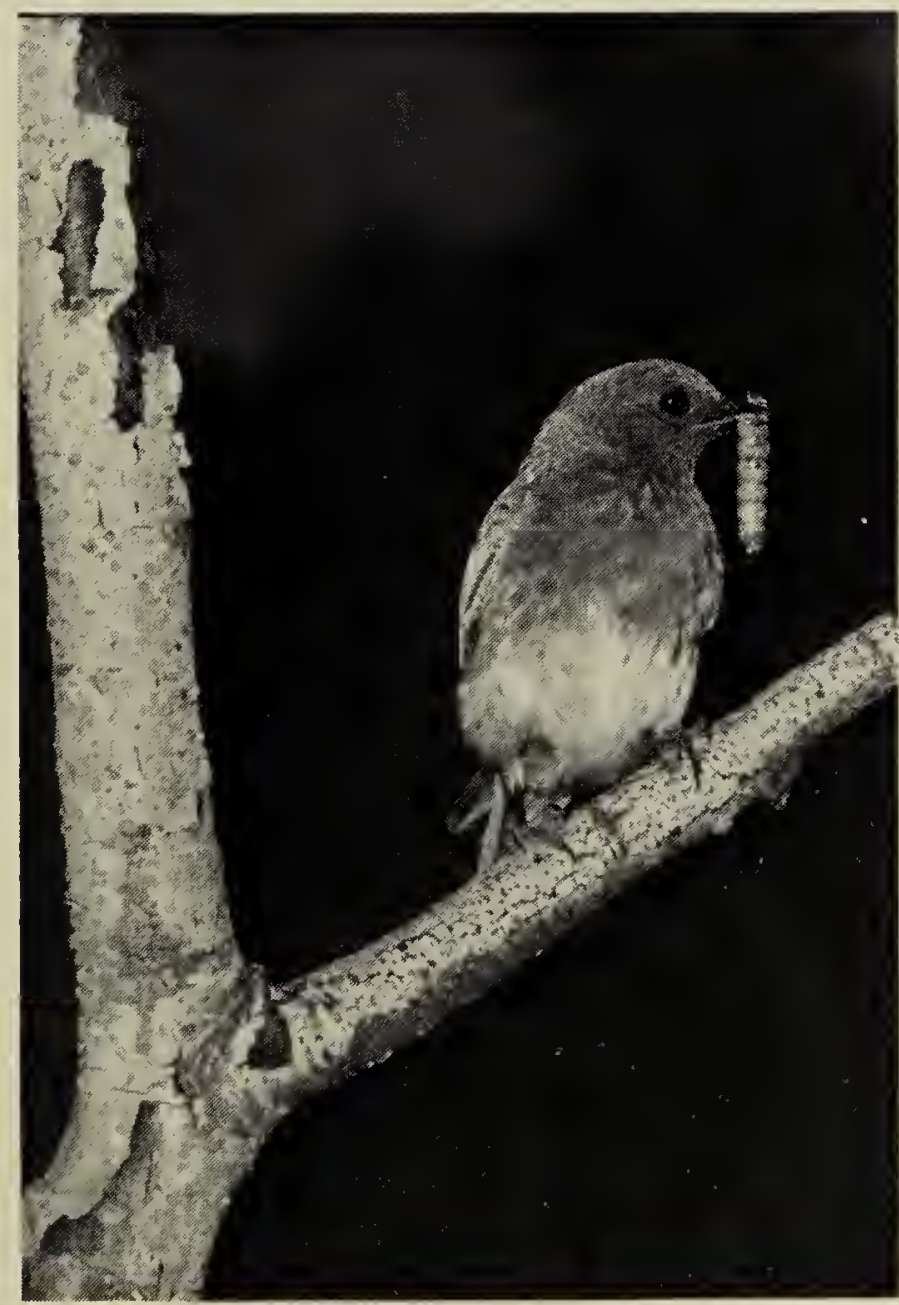

Male Eastern Bluebird
W.J. Walley would appear that this population is maintaining itself, with an average of 1.7 fledged young produced per adult.

Table 3 shows the comparative status of the two bluebirds between Dauphin, Russell and Brandon. Significantly, Mountain Bluebirds are consistently more abundant than Eastern as a breeding bird west, southwest and south of Riding Mountain National Park compared to north of the park. Attention must be drawn to the small number of nest boxes operated out of Dauphin compared to much larger numbers spread over a much more extensive area in southwestern Manitoba maintained by the "Friends of the Bluebirds" out of Brandon and by Jim Spear (also a "Friend of the Bluebirds") of Russell whose lines extend from St. Lazare north to Shellmouth and into Saskatchewan. Nevertheless, the differences in the relative numbers of the two species at Dauphin and in the Russell area have been consistent through 1984 (Table 3). The Brandon area, while reporting considerably larger numbers of Mountain than Eastern from 1981 through 1983, has reported a gradual increase in the relative numbers of Eastern Bluebird nestings. 235 Twice as many were reported in 1983 as there were in 1981. However, a severe mid-May storm in 1983 which devastated nests - eggs and adults, of Mountain Bluebirds probably did not affect the later arriving Easterns as severely. ${ }^{5}$

From 1981 through 1984, 91\% of all bluebird and swallow nestings at Dauphin were Tree Swallow nestings. This compares with a figure of $52 \%$ for the Brandon Russell areas for 1981 through 1983. The much higher percentage of Tree Swallow utilization of nest boxes at Dauphin compared to areas south, southwest and west of Riding Mountain National Park, primarily reflects a much higher Tree Swallow than bluebird population in this area. In 1981, three of four Eastern Bluebird nestings commenced in mid-July immediately after the Tree Swallow families had vacated the nest boxes. 
After the first year (1981) late nestings became the exception rather than the rule and it would appear that once the bluebirds know the location of the nest boxes they find them more quickly the following spring. The only late nesting in 1982 was strongly believed to be a second brood as the adults were observed with young-onthe-wing in a nearby aspen grove during incubation of the second clutch. The young of the presumed second brood were 2 to 3 days from leaving when the nest was visited 23 August. The first family had not been raised in any nest box that we knew about. While the adults were being photographed at the nest box 18 August, it was observed that the female was banded. The bird was caught and released after the number (1221/48553) was triple checked and recorded. This bluebird had been banded as a nestling 21 May, 1979 near Alleman, lowa (about $40 \mathrm{~km}$ north of Des Moines) by D.D. Mosman of Elkhart, lowa. Comparative arrival dates of and competition for nest boxes upon arrival in early spring between Tree Swallows and Eastern Bluebirds at Dauphin require investigation.

The establishment of nest boxes failed to bring about an increase in bluebird nestings as we had hoped (Table 2). The bluebirds favoured three areas, all of which consisted of close-grazed pastures and nearby aspens, and nested in loose colonies. These included the Carmichael-Durston Area southeast of Dauphin, the Starkewski Area to the southwest - both areas just north of the boundary of Riding Mountain National Park - and the Telfer Area northwest of Dauphin. At the Telfer Area three simultaneous nestings were located in little over 1.5 ha (4.5 acres) in 1981. In 1983, three of six nestings occurred within $3 \mathrm{~km}$ in the Starkewski Area while two were within 3 $\mathrm{km}$ in the Carmichael-Durston Area about $8 \mathrm{~km}$ away. In 1984, only one nesting was recorded at Starkewski's despite the fact that two nest boxes were not used by any species in that area. In the same year, five nestings of six nestings occurred in the Carmichael-Durston Area. Colonial nesting or nesting in "pockets" by Eastern Bluebirds was reported by Ann Smith and by Jim Spear (pers. comm.) who observed seven breeding pairs in a small area along the river in the Assiniboine Valley west of Russell in 1974. Another Eastern Bluebird nest was found there in 1981.

It is odd that apparently equal habitats failed to attract any bluebirds. Perhaps strong Tree Swallow competition in these areas explains the absence of bluebirds, but late nestings by bluebirds after the swallows were finished were never attempted in these areas. In one excellent location, European Starlings occurred in nearby aspen groves where they nested in natural cavities, but there was no evidence that they bothered the Tree Swallows that successfully reared young in nest boxes nearby. On the advice of Ann Smith of Brandon to locate nest boxes in sandy areas, 18 were set out along Highway 10 north of Ashville in the spring of 1984. This highway is on the gravel substrate of the former beaches of Lake Agassiz. However, only Tree Swallows used the boxes in the first year. Miller's description of the comparative nesting habitats of Mountain and Eastern Bluebirds suggests that this area of gravel substrate would attract the former. ${ }^{4}$ The area will be watched with interest in 1985 .

In the late summer of 1982, one of a very few House Sparrow nests was found in a nest box in the Telfer Area adjacent to the CNR tracks northwest of Dauphin. In the spring of 1983 House Sparrows were believed to have made their way through $400 \mathrm{~m}$ of aspen forest from the Telfer farmyard to the nest boxes. Despite the fact that one Eastern Bluebird family was successfully reared in late June, the sparrows took over. Sixteen of their nests were terminated in late June and July, but there was no discouraging them. In late July we were forced to remove the nest boxes from the area. An attempt was made to re-establish some of them in late May 1984. Only four boxes were set out. Two weeks later two of the four boxes contained House Sparrow nests 


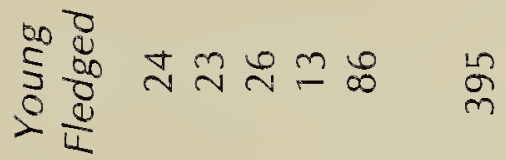

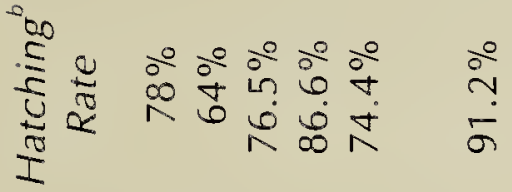

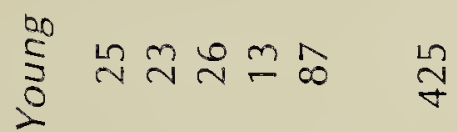

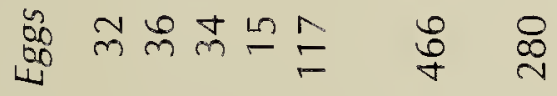

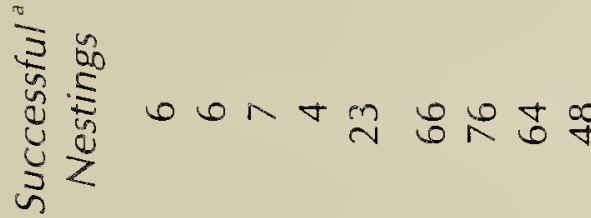

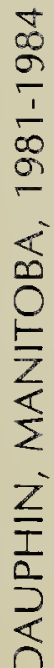
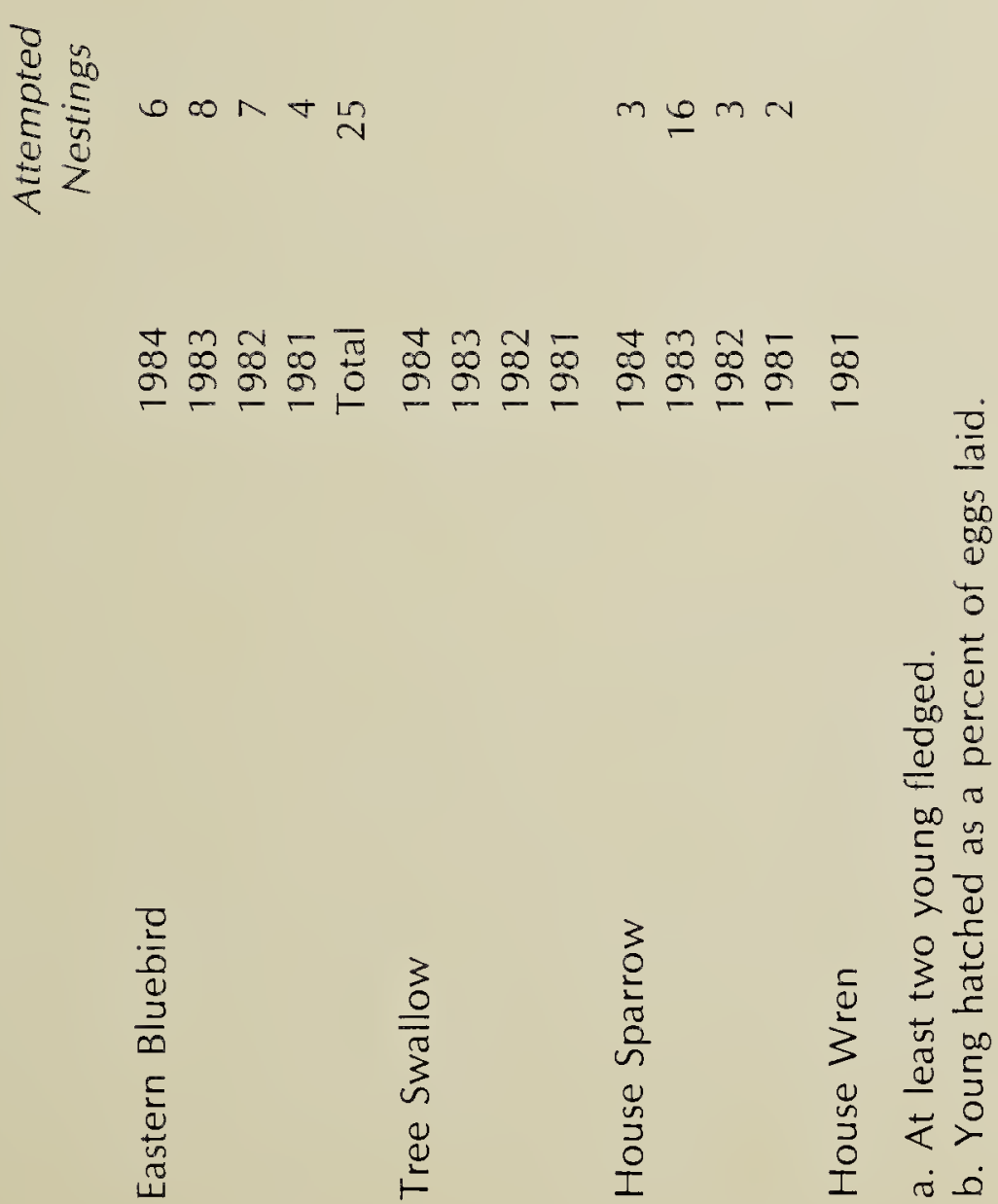


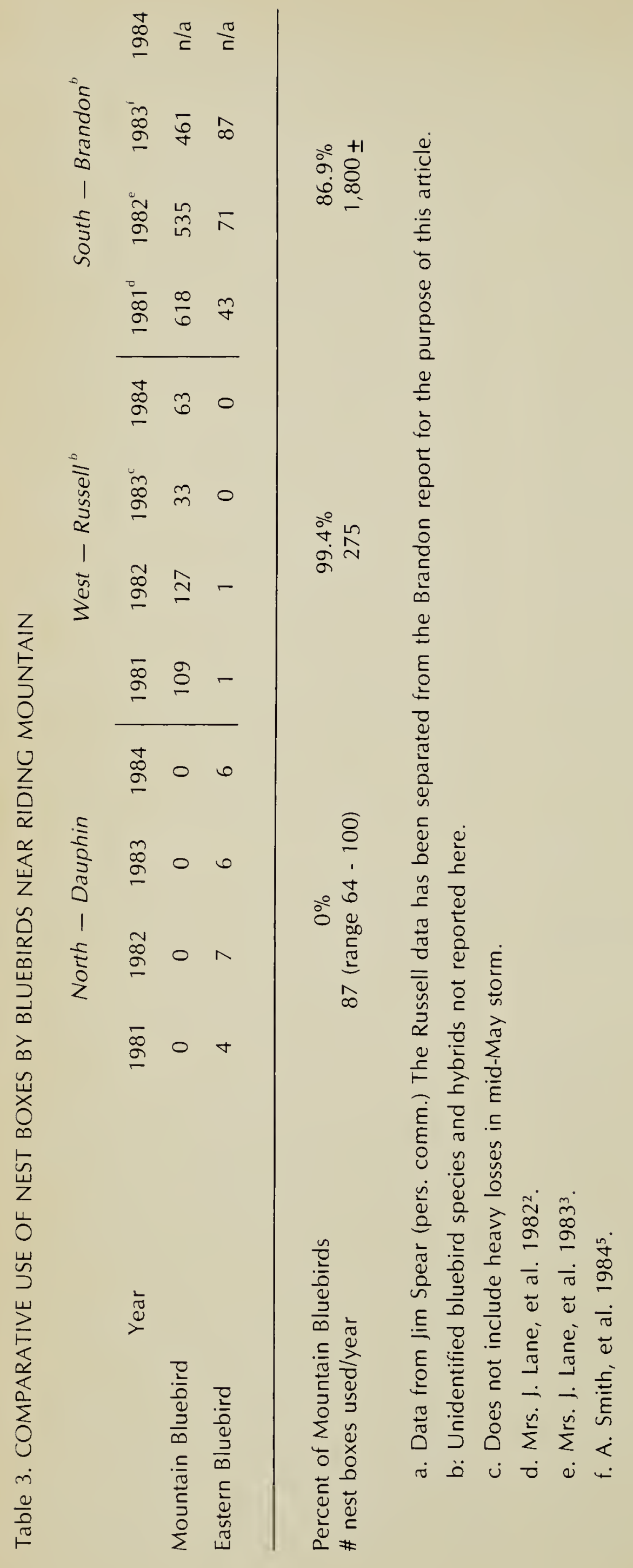




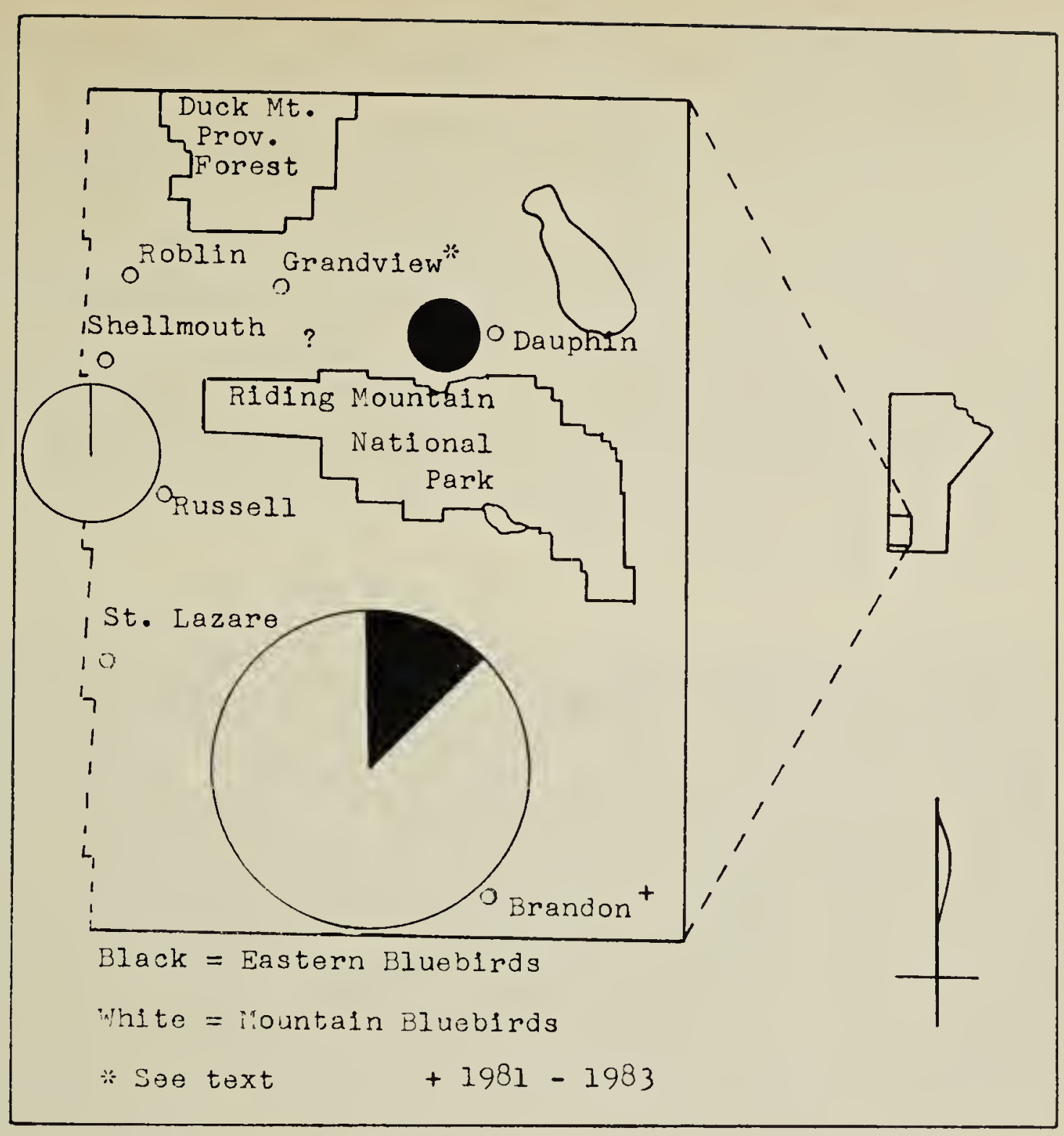

Figure 1. Proportion of Eastern Bluebirds and Mountain Bluebirds in nest boxes in west-central Manitoba, 1981-1984.

and another contained three recently killed adult Tree Swallows - doubtless the work of the sparrows. The 18 attempted House Sparrow nestings here (1983 and 1984) constituted $75 \%$ of all the attempted House Sparrow nestings in our nest boxes in the 4 years.

In 1984, nest box 12 in the CarmichaelDurston Area was occupied by Tree Swallows, so a second nest box (23) was set up only $20 \mathrm{~m}$ away. It was hoped that the swallows in box 12 would, as part of their territorial defense, keep other Tree Swallows out of box 23 thus allowing bluebirds to nest in it. While this ploy had been tried several times by us before without success, it did result in an Eastern Bluebird nesting this time. On 17 June the nest contained five bluebird eggs, but on 19 July the female was incubating eight eggs! About 28 July two eggs hatched and the two young eventually fledged. None of the other six eggs contained discernible embryos. In 1983, nest box 12 contained five white Eastern Bluebird eggs, the only white bluebird eggs observed in the 4-year study. Only two of these eggs hatched. Of 87 young bluebirds that hatched in the 4-year study, 86 fledged. This is a success rate of almost $99 \%$.

With Mountain being the more abundant bluebird south, southwest and west of Riding Mountain National Park and Eastern being the only bluebird to nest in the Dauphin nest boxes, it was of interest to 
know how far west the Eastern breeds north of Riding Mountain National Park (Figure 1). It was deemed appropriate that a nest box line should be operated in the Grandview area to establish the status of the two species there. Ironically, shortly after planning such a line for 1985, the senior author learned from John Ross of Grandview that he had maintained 42 nest boxes on an east-west line a few miles north of the park, south of Grandview, in the summer of 1972. It was with great interest that we learned from Ross that he had had 27 Mountain and 1 Eastern nesting along with 6 Tree Swallows that summer.

Amazingly the Eastern nesting had occurred at the east end of the line - the end closest to Dauphin! Ross has also maintained since 1973 five nest boxes north of Grandview, just outside the Duck Mountain Provincial Forest, in grazed pastures; they have been used regularly by Mountain Bluebirds. Ten houses put up in 1975, 1.5 $\mathrm{km}$ north of Grandview and running east, have been used only by Tree Swallows. Ross plans to resume the next box line south of Grandview in 1985 extending it farther to the east.

'The bluebird data herewith reported for the Dauphin area does not purport to suggest that the Mountain no longer nests in this area. The area covered by the authors is too local. With the exception of the line of 18 nest boxes established north of Ashville in the spring of 1984, all of the boxes at Dauphin would fit within a $35 \mathrm{~km}$ diameter circle. This is too small an area to make generalisations about the region east of Grandview and north of the Riding Mountains. More accurate knowledge concerning the status of the two species here can only be obtained if the trails are expanded, e.g., north to Winnipegosis and east to Ste. Rose du Lac, etc. Our goal now is to recruit assistance to carry out this expansion.

Since the nest box trail was begun in 1981, Robert Carmichael has reported two late season observations at his farm. On 7
October 1982 a flock of 15 Eastern appeared and a single Eastern was seen at a nest box in late October 1983. The earliest record for any bluebird in this general area as observed by the authors was a male Mountain Bluebird seen by Walley just south of Cowan, Manitoba, northeast of the Duck Mountains 15 March 1975. The latest record we know about was that of a male Mountain that showed up in a very weakened condition at the Gene Wilkie farmyard at Dauphin 22 November 1975.

\section{Acknowledgements}

Gratitude is expressed to the following for their bluebird records, observations, advice or hospitality on their farms: Adrian Baker, Robert and David Carmichael, Al and Ruth Pitch, John Ross, Ann Smith, Jim Spear, and Wilf Telfer. Special thanks goes to Howard Cobbe for having the nest boxes constructed at the school. Acknowledgement is made of the late Jack Lane's great enthusiasm back in the early seventies which helped to motivate us to get a nest box line going at Dauphin. Finally, appreciation is extended to John E. Walley who influenced the senior author, his son, to give the bluebirds a helping hand.

1 GODFREY, W.E. 1966. The birds of Canada. Nat. Mus. Canada Bull. 203

2 LANE, Mrs. J., M. McCOWAN, B. ROBINSON, H. PATMORE and A. SMITH. 1982. Twenty-first nest box report from Brandon, Manitoba. Blue Jay $40: 45-47$

${ }^{3}$ LANE, Mrs. J., M. MCCOWAN, B. ROBINSON, H. PATMORE and A. SMITH. 1983. Twentysecond nest box report from Brandon, Manitoba. Blue Jay 41:39-41

${ }^{4}$ MILLER, W. 1970 . Factors influencing the status of Eastern and Mountain Bluebirds in southwestern Manitoba. Blue Jay 28:38-46

5 SMITH, A., N. LANE, H. PATMORE, B. ROBINSON, D. BARNES and M. MCCOWAN. 1984. Twenty-third nest box report from Brandon, Manitoba. Blue Jay 42:42-46

${ }^{6}$ WALLEY, W.J. Personal field notes, 1971-1984. 